University of Vermont

UVM ScholarWorks

College of Agriculture and Life Sciences Faculty

Publications

4-1-2017

\title{
Effect of drive row ground covers on hop (Rosales: Cannabaceae) yard arthropod pests in Vermont, USA
}

\author{
L. Calderwood \\ University of Vermont \\ J. Cubins \\ University of Vermont \\ D. Vesty \\ University of Vermont \\ H. Darby \\ University of Vermont
}

Follow this and additional works at: https://scholarworks.uvm.edu/calsfac

Part of the Agriculture Commons, and the Sustainability Commons

\section{Recommended Citation}

Calderwood L, Cubins J, Vesty D, Darby H. Effect of Drive Row Ground Covers on Hop (Rosales:

Cannabaceae) Yard Arthropod Pests in Vermont, USA. Environmental entomology. 2017 Apr

1;46(2):183-90.

This Article is brought to you for free and open access by the College of Agriculture and Life Sciences at UVM ScholarWorks. It has been accepted for inclusion in College of Agriculture and Life Sciences Faculty Publications by an authorized administrator of UVM ScholarWorks. For more information, please contact scholarworks@uvm.edu. 


\title{
Effect of Drive Row Ground Covers on Hop (Rosales: Cannabaceae) Yard Arthropod Pests in Vermont, USA
}

\author{
L. Calderwood, ${ }^{1,2}$ J. Cubins, ${ }^{1}$ D. Vesty, ${ }^{1}$ and H. Darby ${ }^{3}$
}

1DDepartment of Plant and Soil Science, University of Vermont, 63 Carrigan Dr., Burlington, VT 05405 (Ibc75@cornell.edu; julija. cubins@uvm.edu; dbvesty@uvm.edu), ${ }^{2}$ Corresponding author, e-mail: lbc75@cornell.edu, and ${ }^{3}$ Department of Plant and Soil Science, University of Vermont Extension, 278 South Main St., St. Albans, VT 05478 (hdarby@uvm.edu)

Received 11 January 2016; Accepted 16 May 2016

\begin{abstract}
Alternatives to pesticides are necessary for the management of hop (Humulus lupulus L.) arthropod pests. The three major arthropod pests in northeastern US hop production include two-spotted spider mite, Tetranychus urticae Koch, hop aphid Phorodon humuli (Schrank), and potato leafhopper, Empoasca fabae Harris. This 3-yr study (2012-2014) in Vermont investigated the effect of flowering ground covers on arthropod pest abundance. Hop cultivars 'Nugget' and 'Cascade' were evaluated under a strip-split plot experimental design. Ground cover treatments included 1) Control: mowed red clover (Trifolium pratense) and resident weeds, 2) Clover: red clover, and 3) Diverse: common yarrow (Achillea millefolium), beebalm (Monarda fistulosa), red clover, and annual sunflower (Helianthus annuus). Natural enemies were grouped by associated pest and indicated by our mixed model to be strong predictors of the number of hop aphid and potato leafhopper on hop plants. In year two, ground cover treatment had a significant effect on two-spotted spider mite abundance where fewer two-spotted spider mite were observed on hop plants in Diverse plots. The established, un-mowed Clover treatment was preferred by potato leafhopper over Diverse ground cover and hop plants. This revealed the potential for clover ground cover to serve as a trap crop for potato leafhopper management in northeastern hop yards. Our findings are evidence that ground covers implemented for conservation biological control may serve more specific pest management functions instead of or in addition to boosting top-down pest pressure.
\end{abstract}

Key words: Humulus lupulus, hop, ground cover, trap crop, integrated pest management

Nineteenth-century US hop production took place in the northeast region of the United States. Today, Pacific Northwestern states dominate hop production in the United States. Over the past $10 \mathrm{yr}$ the local food movement has expanded into the beverage market initiating the resurgence of hop production to the northeast. Twospotted spider mites, Tetranychus urticae Koch, and hop aphids Phorodon humuli (Schrank) are the arthropod pests of economic importance in the Pacific Northwest and are continually managed with insecticides (Turner et al. 2011). Potato leafhopper, Empoasca fabae Harris, is native to the northeast and was recognized as a third major arthropod pest in 19th-century northeastern hop production and is also recognized today (Magie 1944, Calderwood et al. 2015). Worldwide, commercial hop producers require alternatives to insecticides in order to strengthen farm ecosystems against pests. The northeast region in particular requires regionally adapted integrated pest management (IPM) tools.

Arthropod communities are a reflection of climate, landscape, and management practices (Schweiger et al. 2005). Habitat management schemes such as flowering ground covers and trap-crops are IPM tools used in agriculture systems. Interrow strips, perimeter vegetation blocks, cover crops, and field edges are examples of habitat that serve as refuge and alternative food resources for natural enemy arthropods. With this type of habitat available, increases in predator and parasitoid abundance has been shown to regulate pest populations in some agriculture systems (Lu et al. 2014). Topdown pest management in IPM today supports the enemies hypothesis presented by Root (1973). It is well understood that some generalist pests, such as potato leafhopper, prefer one vegetation source over another (Straub et al. 2013). Agriculture systems have also successfully incorporated trap-cropping as an IPM tool to manage arthropod pests. For example, western tarnished plant bug (Lygus hesperus Knight) prefers alfalfa over strawberry (Swezey et al. 2007) and pepper maggot (Zonosemata electa Say) prefers hot cherry pepper over bell pepper (Boucher et al. 2003). Insecticides are the go-to management tool for hop arthropod pest suppression. However, the importance of natural enemy ecosystem services in commercial hop yards has been recognized (James 2003, Gent et al. 2009, Woods et al. 2014).

While flowering ground covers in perennial systems have increased natural enemy abundance and therefore decreased pest pressure of spider mites and aphids (Altieri and Schmidt 1986, Alston 1994, Tuovinen 1994, Wyss 1995, Gontijo et al. 2013), their 
implementation has also been shown to increase pest presence (Meagher and Meyer 1989, Goller et al. 1997). Few studies have investigated the effect that ground covers have on hop arthropod pests. A three-year Washington state study indicated that incorporating flowering plants between rows of hops attracted effective natural enemy arthropods. Reliable management of two-spotted spider mite by natural enemies was observed, yet hop aphid populations showed variable population reduction (Grasswitz and James 2009). German research indicated that hop aphid populations were highest on hop plants with mowed fava bean (Vicia faba L.) ground cover (Goller et al. 1997). Ground covers are a logical step toward improving hop production sustainability; however, plant-insect interactions and appropriate ground cover plant species must be identified and evaluated for successful agronomic incorporation (Geneau et al. 2012, Gontijo et al. 2013).

To our knowledge, ground covers have not been evaluated as an IPM tool in northeastern hop production. As potato leafhopper is not a pest in the Pacific Northwest production region, the inclusion of this pest in regional habitat management studies is important. In hopes of reducing pesticide use and spider mite secondary outbreak in hop yards, we hypothesized that flowering ground covers of increasing species diversity would increase natural enemy abundance and therefore reduce hop pest presence in a northeastern hop yard. The objective of this study was to measure the effect of drive row ground covers on the three major arthropod pests in northeastern hop production.

\section{Materials and Methods}

\section{Study Site}

The study was conducted in a certified organic research hop yard located at Borderview Farm in Alburgh, VT $\left(44.97^{\circ} \mathrm{N}, 73.30^{\circ} \mathrm{W}\right.$; Vermont Organic Farmers, LLC, Richmond, VT). The hop yard, established in 2011, consisted of a trellis constructed to a height of $4.8 \mathrm{~m}$ on Benson series silt loam soil. The ground cover trial was initiated in the southern 0.1 ha of the yard where cultivars 'Cascade' and 'Nugget' were planted in alternate rows. The hop yard was surrounded by yearly rotating field crops that included wheat, barley, sunflower, canola, and pasture. Along the eastern edge of the hop yard was a 20 by $200 \mathrm{~m}$ un-mowed pasture strip with two trees in the Ulmus genus. The hop yard is $\sim 300 \mathrm{~m}$ from a hard wood forest, which includes tree species in the genera Acer, Fraxinus, and Betula. These genera are not known to support damaging populations of the major arthropod hop pests.

\section{Experimental Design and Management}

Ground cover treatments were planted on 15 May 2012 in a split strip plot design replicated three times. The main plot was cover crop treatment and the subplot was cultivar. Each main plot was $3.65 \mathrm{~m}$ by $9.14 \mathrm{~m}$ with subplots of $0.9 \mathrm{~m}$ by $9.14 \mathrm{~m}$. Replications alternated with two untreated hop rows and one drive row for a $6-\mathrm{m}$ wide buffer. Ground covers were planted in the drive row between rows of hops. Hop rows were mulched with hardwood bark mulch for weed management. Ground cover treatments included 1) mowed clover and resident weeds (Control) to follow standard grower practices of the region, 2) red clover, Trifolium pratense (Clover), and 3) a diverse mixture of flowering plants including common yarrow, Achillea millefolium, beebalm, Monarda fistulosa, red clover, and annual sunflower, Helianthus annuus cv. 'Durango' (Diverse). Red clover was chosen as a ground cover treatment due to interest from hop growers. The mixture of flowering plants in Diverse plots were chosen with the goal of continued flower from June-August and structural complexity.

The ground cover plots were prepared with a moldboard plow, disked, and finished with a spike tooth harrow. In the Control and Clover treatments red clover was seeded with a Kverneland drill (Keverneland Group, Norway) at a rate of $1.4 \mathrm{~kg} / \mathrm{ha}$ every $11.4 \mathrm{~cm}$ and every $22.8 \mathrm{~cm}$ in Diverse plots. All clover was planted to a depth of $0.64 \mathrm{~cm}$. In addition to seeded clover, rows of yarrow, beebalm, and sunflower were planted in Diverse plots. Rows of 10 plugs/seeds were planted in alternating order for a total of nine rows per mixed species treatment. Second-year plugs of yarrow and beebalm were purchased from North Creek Nurseries (Oxford, PA) and planted by hand. Sunflower seeds were planted in May by hand each season yet only flowered in 2012. The original perennial plugs and red clover seeding remained undisturbed for the duration of the three-year study.

All hop plants were treated with the same agronomic practices. Each spring, two coir strings were clipped into the ground and tied to the top of the trellis at each hill. Three to four hop bines were trained to each string. Hop plants were drip irrigated with 5,977 liter/ha per week June-August in all years of this study. Plots were fertilized with OMRI approved products on 7 May 2012 and 28 May 2013. Fertility rates were $13.8 \mathrm{~kg} / \mathrm{ha}$ plant available $\mathrm{N}, 8.3 \mathrm{~kg} / \mathrm{ha} \mathrm{P}$, and $11.0 \mathrm{~kg} / \mathrm{ha} \mathrm{K}$. In 2013, an additional $11.0 \mathrm{~kg} / \mathrm{ha}$ of sodium nitrate (North Country Organics, Bradford, VT) was applied on 18 June. In 2014, hop plants were amended with sodium nitrate to provide $9.2 \mathrm{~kg} / \mathrm{ha}$ plant available $\mathrm{N}$ at training and an additional $8.5 \mathrm{~kg} /$ ha plant available $\mathrm{N}$ was applied on 27 June. The hop yard was also fertigated on 10 June, 28 June, 4 July, 2014 with soy based FertiNitro Plus produced by Ferti-Organic (Brownsville, TX). Each fertigation application was applied to provide $0.55 \mathrm{~kg} / \mathrm{ha}$ for a total of $1.65 \mathrm{~kg} / \mathrm{ha} \mathrm{N}$ applied via the drip line. Every year, $0.36 \mathrm{~kg} / \mathrm{ha}$ of boron and $0.92 \mathrm{~kg} / \mathrm{ha}$ zinc were applied. Due to the prevalence of hop downy mildew, all hop plants in this study were sprayed with copper hydroxide based fungicide Champ WG (Nufarm Americas Inc, EPA Reg. No. 55146-1) mixed with Regalia (Marrone Bio Innovations, EPA Reg. No. 84059-3) every $7-10 \mathrm{~d}$ at a rate of $0.56 \mathrm{~kg} / \mathrm{ha}$ when plants were under $2.4 \mathrm{~m}$ tall and $1.12 \mathrm{~kg} / \mathrm{ha}$ when plants were over $2.4 \mathrm{~m}$ tall. Insecticides were not applied throughout the duration of the project.

\section{Arthropod Collection}

Arthropods were collected once weekly for 12 consecutive weeks each season. Vacuum, sticky trap, and hand sampling methods were used to collect hop aphid, potato leafhopper, and two-spotted spider mite, respectively. Natural enemy counts on hop plants were collected from vacuum samples. Vacuum samples were also taken from ground cover vegetation plots. All methods of arthropod collection began the first week of June and continued once weekly until harvest began in late August.

\section{Vacuum Sampling}

Of the three middle hills of each cultivar/plot, two hills were chosen at random each week for vacuum sampling. The order in which plants and plots were vacuumed was randomized weekly. Vacuum sampling was performed mid-day between 10 am and 2 pm using a reverse leaf blower with a 25 CC 2-cycle gas engine (Poulan PRO BVM210VS, Charlotte, NC). A 20-cm-long chiffon bag was attached to the end of the vacuum arm to catch the incoming sample. Each hop hill and ground cover plot was vacuumed up and down for $40 \mathrm{~s}$. Ground cover treatments were sampled by zig-zagging 
through the ground vegetation while vacuuming. Samples account for the reachable plant height of $0-3 \mathrm{~m}$. The vacuum was left on while the mesh bag was removed from the vacuum. The sample was placed into a kill jar containing ethyl acetate and left for 2-5 min. Arthropod samples in kill jars were then transferred into labeled $250-\mathrm{ml}$ glass jars containing $30 \mathrm{ml} 70 \%$ ethyl alcohol for later lab sorting. This sampling method was used to report hop aphid and natural enemies on hop plants in addition to pests and natural enemies from the ground cover vegetation. While leaf counts are the reported method of aphid measurement in hops (Gent et al. 2009 and Lorenzana et al. 2009), vacuum sampling for aphids has been conducted in wheat (Burd et al. 2006).

\section{Sticky Traps}

Sticky traps were un-baited 7.6 - by $12.7-\mathrm{cm}$ yellow cards hung between the two strings of the middle plant in each plot, $2 \mathrm{~m}$ off the ground on coir rope held with wooden close-pins. There was one trap/variety/plot hung between bines on the center plant for a total of 18 traps weekly. Traps were hung after vacuum sampling each week and collected before vacuum sampling the following week. This method of collection was used to report potato leafhopper on hop plants.

\section{Hand Sampling}

Directly following vacuum sampling, arthropods remaining on leaves were field identified, counted, and recorded with an OptiVISOR Headband Magnifier (1.5× magnification, Donegan Optical Co., Lanexa, KS) on three randomly chosen leaves per vacuumed plant. This method of collection was used to report twospotted spider mite on hop plants.

\section{Arthropod Identification}

Vacuum and sticky trap samples were sorted into pest and natural enemy groups using a Zeiss Stemi DV4 stereo microscope (Carl Zeiss MicroImaging GmbH, Germany). Major pest arthropods were identified to species while natural enemies were identified to functional group. Major pest arthropods included hop aphid, potato leafhopper, and two-spotted spider mite. Natural enemy groups were formed based on previous studies that show predation or parasitism of hop aphid, potato leafhopper, and two-spotted spider mite (Table 1). Parasitoid families included Mymaridae, Chalcidoidea, Braconidae, Aphelinidae (Lovinger et al. 2000) and were not sorted separately but lumped into one "parasitica” category.

\section{Hop Harvest Yield and Quality}

'Cascade' and 'Nugget' were harvested when the cones reached $23 \%$ dry matter. 'Cascade' was harvested on 4 September 2012 and on 28 August in 2013 and 2014. 'Nugget' was harvested on 11 September in 2012 and 2013 and on 3 September, 2014. Hop bines were cut in the field and harvested within $4 \mathrm{~h}$. Bine pre-pick and total cone weights were recorded. Percent dry matter and total cone weights were determined at harvest. Harvested hops were air dried in a $40.5^{\circ} \mathrm{C}$ oast. Once hops reached $92 \%$ dry matter (typically overnight) a representative $100 \mathrm{~g}$ sample of each cultivar in each plot was collected. Alpha Analytics in Yakima, WA, analyzed samples for alpha and beta acid percentage according to the American Society of Brewing Chemists methodology.

\section{Data Analysis}

Arthropod count data were square root transformed. A linear mixed model with repeated measures (PROC MIXED, SAS Institute 2014)
Table 1. Natural enemy arthropod groupings for each major hop pest species

\begin{tabular}{ll}
\hline Pest & \multicolumn{1}{c}{ Natural enemy group } \\
\hline $\begin{array}{c}\text { Tetranychus urticae } \\
\text { (two-spotted spider mite) }\end{array}$ & Stethorus punctum \\
$\begin{array}{c}\text { Phorodon humuli } \\
\text { (hop aphid) }\end{array}$ & Anthocoridae \\
& Anthocoridae, Geocoridae, Nabidae \\
& Chrysopidae \& Hemerobiidae \\
& Coccinellidae \\
& Parasitica \\
& Syrphidae \\
Empoasca fabae & Anthocoridae, Geocoridae, Nabidae \\
(potato leafhopper) & Chrysopidae \& Hemerobiidae \\
& Coccinellidae \\
& Parasitica \\
& Araneae
\end{tabular}

was used to evaluate pest arthropods by ground cover treatment, cultivar, and collection date for each collection method. Vacuum plant, vacuum ground cover, hand sampling, and sticky trap samples were analyzed separately because collection methods did not have the same sampling unit, however similar analyses were conducted. Natural enemy group was included in the model as a continuous covariate due to the amount of variation accounted for by this variable. Factors were considered fixed with the exception of replication. Fixed effects included natural enemy group, natural enemy group $\times$ treatment, cultivar, ground cover treatment, treatment $\times$ cultivar, collection date, cultivar $\times$ collection date, and treatment $\times$ collection date. Natural enemy group $\times$ treatment was removed from the model because it was not significant.

In vacuum plant, hand, and sticky trap models, hop plant was the experimental unit measured repeatedly over time. On plants two-spotted spider mite are reported using the hand sampling model, hop aphid are reported using the vacuum model, and potato leafhopper are reported using the sticky trap model. For the vacuum ground cover vegetation model, ground cover plot was the experimental unit measured repeatedly over time. Statistics for pests are reported using the vacuum ground cover model. Years were not pooled.

Hop quality is represented using alpha and beta acid percentage. Yield was calculated using a hop population of 784 hills per acre. Ground cover treatment yield and quality were compared using the general linear model procedure (PROC GLM, SAS Institute 2014). Yield and quality data were run separately and included the same fixed effects: year, cultivar, year $\times$ cultivar, cover crop treatment, year $\times$ treatment, cultivar $\times$ treatment, and year $\times$ cultivar $\times$ treatment. All statistics were run at the 0.05 level of significance (LOS) and generated using SAS software, Version 9.4 (Copyright 2014 by SAS Institute Inc., Cary, NC).

\section{Results}

\section{Effect of Cover Crop and Cultivar on Arthropod Pests on Hop Plants}

Detail sampling counts taken after vacuuming was not an ideal collection method for two-spotted spider mite. However, counts indicated that the most abundant two-spotted spider mite populations were present in 2012 and 2014. The season of 2013 had the lowest two-spotted spider mite population when two-spotted spider mite natural enemies were a strong predictor of two-spotted spider mite on hop plants (Table 2). The effect of cultivar on two-spotted spider 
mite was significant in 2014 where 'Nugget' had higher abundance than 'Cascade'. Ground cover treatment had a significant effect on the two-spotted spider mite population in 2013 where hop plants in Diverse plots had significantly fewer two-spotted spider mite. No significant interaction effects were observed. The effect of collection date was significant as expected in all years (Table 2).

Vacuum samples indicated that the hop aphid population was highest in the cool, moist season of 2013. Hop aphid natural enemies were a strong predictor of this pest in all years (Table 3). The effect of cultivar was significant in 2013, with 'Nugget' having higher aphid abundance than 'Cascade'. The effect of ground cover treatment did not have a significant effect on hop aphid populations. There were no significant interaction effects. The effect of collection date was significant in all years as expected (Table 3).

Potato leafhopper were most abundant in 2012 and 2013 on sticky traps. In 2014, potato leafhopper arrived late with a population approximately half the size of the previous two years. Populations of potato leafhopper peaked on 10 July in 2012 and 2013. The 2014 potato leafhopper migration was low and late, peaking on 12 August (Fig. 5). The effect of cultivar on potato leafhopper was significant in 2013 with higher abundance observed on 'Nugget'. Also in 2013, there was a significant effect of treatment where a higher number of potato leafhopper were observed on hop plants in Diverse treatments (Fig. 1). There was no significant interaction between treatment and cultivar. Collection date was significant as expected. Potato leafhopper cultivar $\times$ date and treatment $\times$ date interactions were not significant (Table 4).

\section{Effect of Ground Covers on Arthropod Pests in Ground Cover Vegetation}

Natural enemies of two-spotted spider mite were not a strong predictor of spider mites in ground cover vegetation. The effect of treatment did not significantly impact two-spotted spider mite abundance. Collection date had a significant effect in 2013 and 2014. There was a significant treatment $\times$ date interaction in 2014 where Clover vegetation had the highest mean two-spotted spider mite population at the end of July followed by a peak in Control plots before harvest (Supp. Table 1 [online only]).

Hop aphid natural enemies were a strong predictor of this pest in all years. The effect of treatment on hop aphid was not significant. Collection date had a significant effect on hop aphid populations in 2012 and 2013. There was not a significant interaction between treatment and collection date for hop aphid (Supp. Table 2 [online only]).

Vacuum samples from ground cover plot vegetation indicated that potato leafhopper natural enemies were strong predictors of this pest in all years (Table 5). The effect of treatment was significant in 2012 when potato leafhopper mean abundance was highest in Diverse vegetation and in 2013 when potato leafhopper abundance was highest in Clover vegetation (Figs. 2 and 3). The effect of collection date was significant in all years. There was a significant treatment $\times$ date interaction in 2014. In this low population year potato leafhopper had the highest population in Diverse plots which declined earlier than potato leafhopper in Control and Clover vegetation. Clover typically reached senescence by early August. The 2014 potato leafhopper population arrived after clover senescence and therefore showed a trend toward higher potato leafhopper in Diverse plot vegetation (Table 5; Fig. 4).

\section{Hop Harvest Yield and Quality}

Year had a significant effect on hop yield. Mean 'Cascade' yield increased over the course of this three-year study from $56.04 \mathrm{~kg} / \mathrm{ha}$ in 2012 to $134.49 \mathrm{~kg} / \mathrm{ha}$ in 2014. Mean 'Nugget' yield increased from $77.02 \mathrm{~kg} / \mathrm{ha}$ to $139.87 \mathrm{~kg} / \mathrm{ha}$ in 2014 . Year also had a significant effect on 'Cascade' and 'Nugget' alpha and beta acids. As expected the effect of cultivar on yield and quality were significant. There was

Table 2. ANCOVA summary statistics for two-spotted spider mite from hand sampling, with $F$ values and significance from linear mixed model with repeated measures reported for 2012, 2013, and 2014

\begin{tabular}{|c|c|c|c|c|c|c|}
\hline \multirow{2}{*}{$\begin{array}{l}\text { Effects } \\
\text { Two-spotted spider mite }\end{array}$} & \multicolumn{2}{|c|}{2012} & \multicolumn{2}{|c|}{2013} & \multicolumn{2}{|c|}{2014} \\
\hline & $F(\mathrm{n}, \mathrm{d})$ & Sig. & $F(\mathrm{n}, \mathrm{d})$ & Sig. & $F(\mathrm{n}, \mathrm{d})$ & Sig. \\
\hline Natural enemy group & $0.1(1,156)$ & 0.71 & $11.5(1,131)$ & 0.0009 & $0.3(1,161)$ & 0.58 \\
\hline Cultivar & $0.01(1,46.5)$ & 0.90 & $0.1(1,56.1)$ & 0.80 & $5.3(1,53.5)$ & 0.0258 \\
\hline Treatment & $1.3(2,45.8)$ & 0.28 & $3.1(2,56.8)$ & 0.0544 & $0.4(2,53.3)$ & 0.69 \\
\hline Treatment $\times$ cultivar & $0.6(2,47.2)$ & 0.53 & $0.2(2,54.9)$ & 0.81 & $0.5(2,54.3)$ & 0.60 \\
\hline Date & $22.6(11,40)$ & $<0.0001$ & $31.3(10,123)$ & $<0.0001$ & $11.5(11,140)$ & $<0.0001$ \\
\hline Cultivar $\times$ date & $0.77(11,139)$ & 0.67 & $0.2(10,123)$ & 1.00 & $0.86(11,139)$ & 0.58 \\
\hline Treatment $\times$ date & $1.16(22,142)$ & 0.29 & $0.6(20,127)$ & 0.90 & $1.2(22,142)$ & 0.28 \\
\hline
\end{tabular}

Table 3. ANCOVA summary statistics for hop aphid from vacuum samples, with $F$ values and significance from linear mixed model with repeated measures reported for 2012, 2013, and 2014

\begin{tabular}{|c|c|c|c|c|c|c|}
\hline \multirow{2}{*}{$\begin{array}{l}\text { Effects } \\
\text { Hop aphid }\end{array}$} & \multicolumn{2}{|c|}{2012} & \multicolumn{2}{|c|}{2013} & \multicolumn{2}{|c|}{2014} \\
\hline & $F(\mathrm{n}, \mathrm{d})$ & Sig. & $F(\mathrm{n}, \mathrm{d})$ & Sig. & $F(\mathrm{n}, \mathrm{d})$ & Sig. \\
\hline Natural enemy group & $16.6(1.350)$ & $<0.0001$ & $20.4(1,381)$ & $<0.0001$ & $40.6(1,366)$ & $<0.0001$ \\
\hline Cultivar & $1.6(1,72.9)$ & 0.21 & $7.0(1,110)$ & 0.0092 & $2.9(1,117)$ & 0.09 \\
\hline Treatment & $0.1(2,73.1)$ & 0.89 & $1.3(2,104)$ & 0.28 & $0.5(2,111)$ & 0.59 \\
\hline Treatment $\times$ cultivar & $0.0(2,79.4)$ & 0.99 & $2.2(2,109)$ & 0.12 & $0.0(2,113)$ & 0.99 \\
\hline Date & $5.9(11,322)$ & $<0.0001$ & $27.6(11,328)$ & $<0.0001$ & $20.6(11,321)$ & $<0.0001$ \\
\hline Cultivar $\times$ date & $0.7(11,323)$ & 0.70 & $1.6(11,326)$ & 0.10 & $1.5(11,321)$ & 0.14 \\
\hline Treatment $\times$ date & $0.7(22,327)$ & 0.84 & $0.9(22,336)$ & 0.65 & $0.8(22,328)$ & 0.62 \\
\hline
\end{tabular}


a significant year $\times$ cultivar interaction in hop quality as expected due to known differences in quality parameters between the two cultivars. Cover crop treatment did not have an effect on hop yield or quality measures taken. Additionally, year $\times$ treatment and cultivar $\times$ treatment interactions were not significant. The year $\times$ cultivar $\times$ treatment three-way interaction was not significant (Table 6).

\section{Discussion}

Our results indicate that the flowering ground cover treatments tested significantly effected the low two-spotted spider mite of 2013 and exposed a plant-pest interaction between potato leafhopper and clover ground cover. The abundance of hop aphid on hop plants was not significantly effected by ground cover treatments. Regardless of ground cover treatment, natural enemy groups were strong predictors of hop aphid and potato leafhopper. However, we do not believe that our ground cover plots were spatially independent for an accurate measure of pest regulation by natural enemies. Whether the natural enemy community was enhanced by our ground cover treatments or the surrounding diverse research farm habitat, we cannot conclude. Two-spotted spider mite has been documented as an economically damaging pest in hot, dry conditions (Mahaffee et al. 2009) while hop aphid populations become economically detrimental to cone quality in cooler, moist years in the Pacific Northwest and European production regions (Mahaffee et al. 2009, Lorenzana et al. 2013). These pests did not reach outbreak levels in our hop yard, which made insecticide application

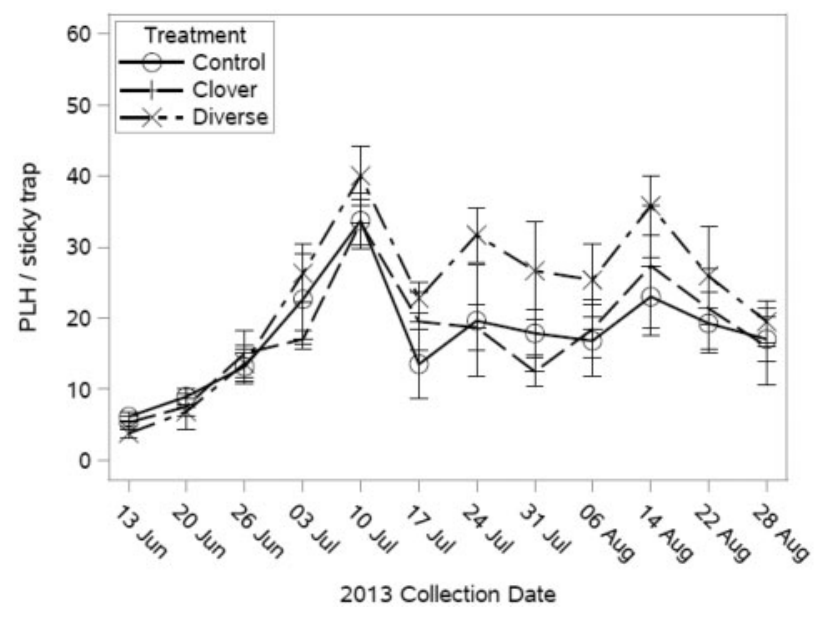

Fig. 1. Mean potato leafhopper (PLH)/sticky trap on hop plants in 2013 by cover crop treatment. Cultivars were combined. There was a significantly higher number of potato leafhopper on hop plants in Diverse plots $(P=0.01)$. unnecessary. This is evidence that natural enemies have the potential to be an IPM tool in northeastern hop yards. The established, unmowed red clover treatment served as a trap crop for potato leafhopper in the second year of this study (Table 5; Figs. 2, 3, 4 and 5). This suggests that ground cover in northeastern hop production may serve more specific pest management functions in lieu of boosting overall natural enemy abundance. Hop yield and quality measures collected at harvest were not significantly effected by the presence of ground cover treatments.

We observed similar pest management results to the Washington state flowering ground cover study. Grasswitz and James et al. (2009) showed a significant reduction in two-spotted spider mite in the second two years of their study and variable reduction in hop aphid populations on hop foliage in response to flowering ground cover. In year two of our study, there was a significantly lower abundance of two-spotted spider mite on hop plants in Diverse plots and two-spotted spider mite natural enemies were a strong predictor of two-spotted spider mite. The lowest two-spotted spider mite population was observed in this year. Ground cover treatments did not effect hop aphid populations in our study.

Clover ground cover has the potential to become an IPM tool for northeastern hop growers. The nonmowed, fully established Clover plots were more attractive to potato leafhopper than Diverse plots and hop plants, indicating that clover may be able to serve as a trap crop for potato leafhopper in this system. Clover ground cover was establishing in 2012 when potato leafhopper were highest in Diverse ground cover vegetation (Fig. 3). In 2013, potato leafhopper numbers were highest on hop plants in Diverse plots yet highest in the Clover vegetation. This indicates that a full stand of clover was preferred by potato leafhopper over hop plants and the Diverse polyculture ground cover treatment. While clover was a member of the Diverse treatment mix there was a lower density of clover in Diverse plots. Straub et al. (2013) provided evidence of the same phenomenon in alfalfa where potato leafhopper populations were higher in alfalfa monocultures than in mixed species alfalfa stands.

Our research indicated that neither hop yield nor quality differed between ground cover treatments in the first three years of their presence. Future studies should expand measures of hop harvest quality to include essential oil content in addition to the alpha and beta acid measures reported here. There is concern among hop researchers and growers that the presence of un-mowed ground clover would increase the presence of hop downy mildew an economically damaging oomycete pathogen of major concern in hop production (Mahaffee et al. 2009, Gent et al. 2010) and compete for nutrients with hop plants. Assuming that we would have seen a significant effect on yield and quality between treatments if enough moisture was trapped to increase downy mildew presence, the ground covers of the stature and density used in this study did not yet contribute to

Table 4. ANCOVA summary statistics for potato leafhopper from sticky traps, with $F$ values and significance from linear mixed model with repeated measures reported for 2012, 2013, and 2014

\begin{tabular}{|c|c|c|c|c|c|c|}
\hline \multirow{2}{*}{$\begin{array}{l}\text { Effects } \\
\text { Potato leafhopper }\end{array}$} & \multicolumn{2}{|c|}{2012} & \multicolumn{2}{|c|}{2013} & \multicolumn{2}{|c|}{2014} \\
\hline & $F(\mathrm{n}, \mathrm{d})$ & Sig. & $F(\mathrm{n}, \mathrm{d})$ & Sig. & $F(\mathrm{n}, \mathrm{d})$ & Sig. \\
\hline Natural enemy group & $5.92(1,131)$ & 0.0164 & $15.77(1,142)$ & 0.0001 & $5.10(1,150)$ & 0.0254 \\
\hline Cultivar & $2.64(1,33.3)$ & 0.11 & $4.51(1,63.7)$ & 0.0376 & $0.96(1,34.5)$ & 0.33 \\
\hline Treatment & $0.12(2,32.7)$ & 0.89 & $4.60(2,63.8)$ & 0.0137 & $0.27(2,34.2)$ & 0.76 \\
\hline Treatment $\times$ cultivar & $0.45(2,33.7)$ & 0.64 & $.35(2,62.8)$ & 0.70 & $0.02(2,36.5)$ & 0.98 \\
\hline Date & $34.40(11,124)$ & $<0.0001$ & $5.74(11,140)$ & $<0.0001$ & $32.70(11,143)$ & $<0.0001$ \\
\hline Cultivar $\times$ date & $0.73(11,120)$ & 0.71 & $0.69(11,140)$ & 0.75 & $0.93(11,142)$ & 0.51 \\
\hline Treatment $\times$ date & $0.41(22,122)$ & 0.99 & $0.70(22,142)$ & 0.84 & $0.69(22,143)$ & 0.84 \\
\hline
\end{tabular}




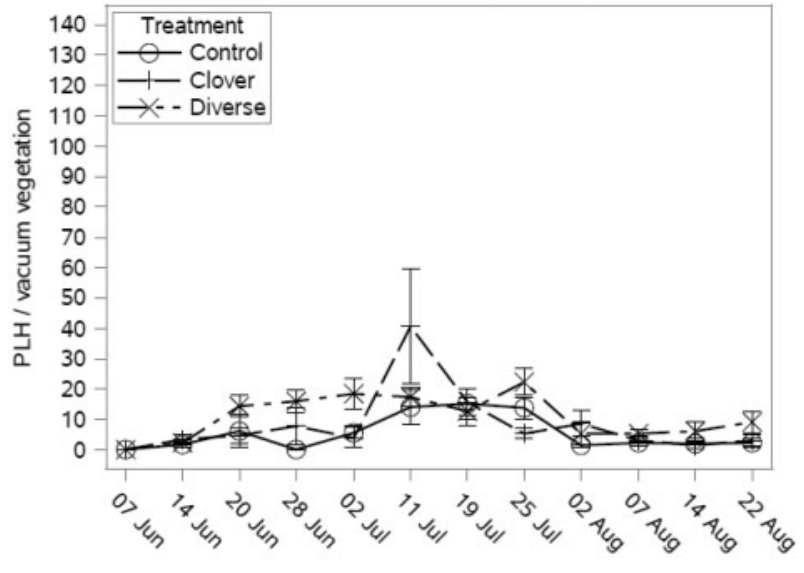

2012 Collection Date

Fig. 2. Mean potato leafhopper (PLH)/vacuum sample in 2012 cover crop vegetation by treatment. There was significantly higher mean potato leafhopper abundance in Diverse cover crop plots $(P=0.04)$, yet Cover plot vegetation spiked highest.

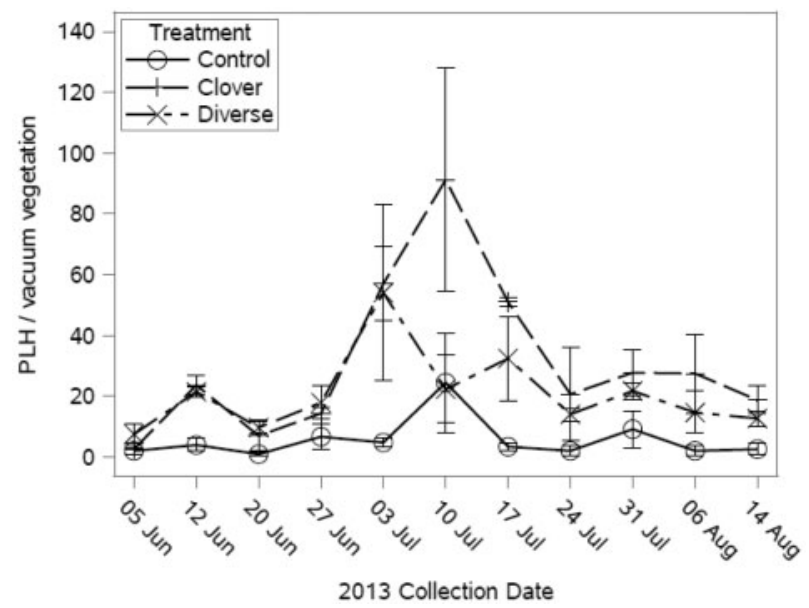

Fig. 3. Mean number potato leafhopper (PLH)/vacuum sample in 2013 cover crop vegetation by treatment. There was a significantly higher number of potato leafhopper in Clover cover crop treatments.

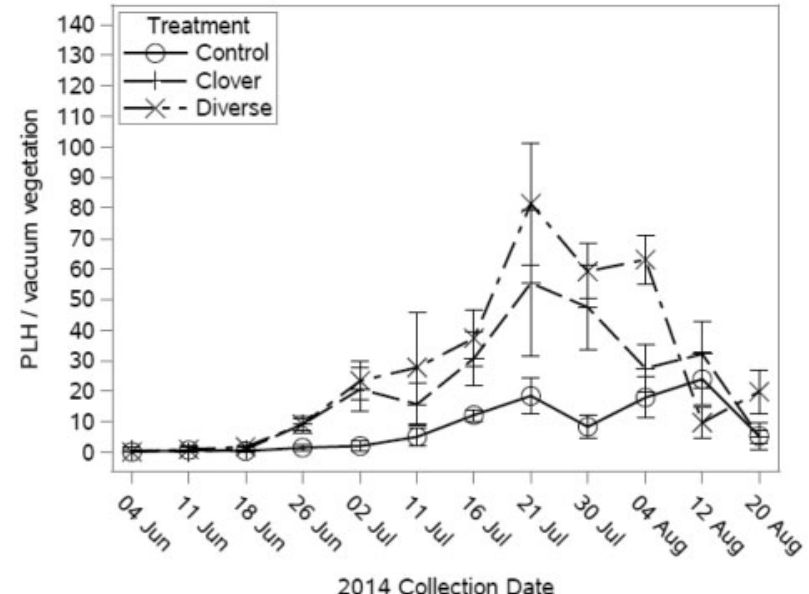

Fig. 4. Mean potato leafhopper (PLH)/vacuum sample in 2014 cover crop vegetation by treatment. There was not a significantly higher number of potato leafhopper in Diverse cover crop treatments, yet a noteworthy trend was observed.

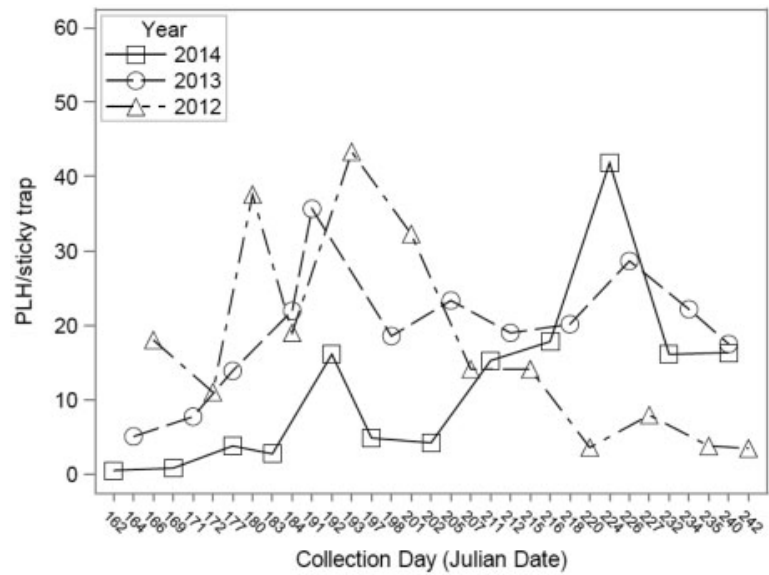

Fig. 5. Phenology of potato leafhopper (PLH) by year on hop plants from sticky traps. Cultivars were combined. The effect of collection date was significant in all years with populations of potato leafhopper peaking on 10 July in 2012 and 2013. In 2014, potato leafhopper peaked on 12 August.

Table 5. ANOVA summary statistics for potato leafhopper in ground cover vegetation from vacuum sampling; $F$ values and significance from linear mixed model with repeated measures are reported for 2012, 2013, and 2014.

\begin{tabular}{|c|c|c|c|c|c|c|}
\hline \multirow{2}{*}{$\begin{array}{l}\text { Effects } \\
\text { Potato leafhopper }\end{array}$} & \multicolumn{2}{|c|}{2012} & \multicolumn{2}{|c|}{2013} & \multicolumn{2}{|c|}{2014} \\
\hline & $F(\mathrm{n}, \mathrm{d})$ & Sig. & $F(\mathrm{n}, \mathrm{d})$ & Sig. & $F(\mathrm{n}, \mathrm{d})$ & Sig. \\
\hline Natural enemy group & $25.3(1,63.5)$ & $<0.0001$ & $41.7(1,63.3)$ & $<0.0001$ & $19.0(1,66.2)$ & $<0.0001$ \\
\hline Treatment & $3.8(2,17.4)$ & 0.0415 & $6.9(2,20.1)$ & 0.0050 & $1.5(2,21.1)$ & 0.26 \\
\hline Date & $6.7(11,58.8)$ & $<0.0001$ & $4.3(10,52.5)$ & 0.0002 & $10.5(11,60)$ & $<0.0001$ \\
\hline Treatment $\times$ date & $1.6(22,56.1)$ & 0.07 & $1.4(20,49.8)$ & 0.17 & $3.5(22,56.6)$ & $<0.0001$ \\
\hline
\end{tabular}

the presence of hop downy mildew. However, farms have different microclimates. Alburgh, VT, is located on a peninsula that reaches out into Lake Champlain and is therefore a well-ventilated, windy site for a hop yard. Unfortunately, our study did not include measures of downy mildew or nutrient uptake.

Pest management needs of northeastern hop yards are different from the needs of other production regions. Agricultural field size has an effect on hop arthropod pest pressure as evidenced by
Schweiger et al. (2005). The average hop yard size in the Yakima Valley of Washington is 182.0 ha (USA Hops 2008) while northeastern yards currently range from $0.4-8.0$ ha. Northeastern researchers and farmers have adopted Pacific Northwestern management practices while our eastern hop yards are more comparable in size and surrounding landscape to those in Europe. Even so, the findings presented here indicate that both Washington (Grasswitz and James 2009) and Vermont hop yards benefitted from one or more aspects 
Table 6. ANCOVA summary statistics for yield, alpha acid, and beta acid percent, with $F$ values and significance values presented from generalized mixed model

\begin{tabular}{|c|c|c|c|c|c|c|}
\hline \multirow[t]{2}{*}{ Effects } & \multicolumn{2}{|c|}{ Yield } & \multicolumn{2}{|c|}{$\alpha \operatorname{acid}(\%)$} & \multicolumn{2}{|c|}{$\beta \operatorname{acid}(\%)$} \\
\hline & $F(\mathrm{n}, \mathrm{d})$ & Sig. & $F(\mathrm{n}, \mathrm{d})$ & Sig. & $F(\mathrm{n}, \mathrm{d})$ & Sig. \\
\hline Year & $28.6(2,35)$ & $<0.0001$ & $4.8(2,30)$ & 0.0151 & $6.7(2,30)$ & 0.004 \\
\hline Cultivar & $8.7(1,35)$ & 0.0055 & $1035.3(1,30)$ & $<0.0001$ & $348.8(1,30)$ & $<0.0001$ \\
\hline Year $\times$ cultivar & $1.7(2,35)$ & 0.19 & $21.1(2)$ & $<0.0001$ & $11.1(2,30)$ & 0.0002 \\
\hline Treatment & $0.5(2,35)$ & 0.62 & $0.0(2,30)$ & 0.99 & $0.2(2,30)$ & 0.82 \\
\hline Year $\times$ treatment & $0.4(4,35)$ & 0.82 & $2.1(4)$ & 0.11 & $0.2(4,30)$ & 0.94 \\
\hline Cultivar $\times$ treatment & $0.1(2,35)$ & 0.91 & $1.0(2,30)$ & 0.37 & $0.04(2,30)$ & 0.96 \\
\hline Year $\times$ cultivar $\times$ treatment & $0.8(4,35)$ & 0.50 & $0.25(4)$ & 0.91 & $0.7(4.30)$ & 0.63 \\
\hline
\end{tabular}

of the implemented habitat diversity. We encourage further research on natural enemy management of hop arthropod pests where hop yard size and surrounding habitat are central. Before implementing clover in hop yards as a trap-crop for potato leafhopper management, further research should address trap crop size, orientation, carrying capacity, and air circulation for disease control. As the northeast continues to develop an IPM program for hop it is important that arthropod and disease management are studied in concert.

Finally, ground cover treatments planted between hop rows in Alburgh, VT, had a significant effect on the two-spotted spider mite in the second year and revealed the potential for un-mowed clover to serve as a potato leafhopper trap crop in northeastern hop yards. Our findings are evidence that ground covers implemented for conservation biological control may serve more specific pest management functions in addition to boosting top-down pest pressure.

\section{Acknowledgments}

We would like to thank Alan Howard for assistance with data analyses, the UVM Extension Northwest Crops and Soils Team for data collection and insect sorting, and Roger Rainville of Borderview Farm for his participation and equipment expertise in this study. This work would not have been possible without financial support from Northeast Sustainable Agriculture Research and Education (SARE) program (GNE12-033), Vermont State Agricultural Experiment Station Hatch program (VT HO2013), and the US Environmental Protection Agency (EPA) PestWise program (83558401).

\section{References Cited}

Altieri, M., and L. Schmidt. 1986. Cover crops affect insect and spider populations in apple orchards. Calif. Agric. Jan-Feb: 1-3.

Alston, D. 1994. Effect of apple orchard floor vegetation on density and dispersal of phytophagous and predaceous mites in Utah. Agric. Ecosyst. Environ. 50: 73-84.

Boucher, J., R. Ashley, R. Durgy, M. Sciabarrasi, and W. Calderwood. 2003. Managing the pepper maggot (Diptera: Tephritidae) using perimeter trap cropping. J. Econ. Entomol. 96: 420-432.

Burd, J., D. Porter, G. Puterka, and S. Haley. 2006. Biotype variation among North American Russian wheat aphid (Homoptera: Aphididae) populations. J. Econ. Entomol. 99: 1862-1866.

Calderwood, L., S. Lewins, and H. Darby. 2015. Survey of Northeastern Hop arthropod pests and their natural enemies. J. Integr. Pest Manage. 6: 1-14.

Geneau, C., W. Felix, H. Luka, C. Daniel, and O. Balmer. 2012. Selective flowers to enhance biological control of cabbage pests by parasitoids. Basic Appl. Ecol. 13: 85-93.

Gent, D., D. James, L. Wright, D. Brooks, J. Barbour, A. Dreves, A. G. Fisher, and V. Walton. 2009. Effects of powdery mildew fungicide programs on two-spotted spider mite (Acari: Tetranychidae), hop aphid (Hemiptera: Aphididae), and their natural enemies in hop yards. Hortic. Entomol. 102: 274-286.
Gent, D., C. Ocamb, and J. Farnsworth. 2010. Forecasting and Management of Hop Downy Mildew. Plant Dis. 94: 425-431.

Goller, E., L. Nunnenmacher, and H. Goldbach. 1997. Faba beans as a cover crop in organically grown hops: Influence on aphids and aphid antagonists. Biol. Agric. Hort. 15: 279-284.

Gontijo, L., F. Beers, and W. Snyder. 2013. Flowers promote aphid suppression in apple orchards. Biol. Control 66: 8-15.

Grasswitz, T., and G. James. 2009. Influence of hop yard ground flora on invertebrate pests of hops and their natural enemies. J. Appl. Entomol. 133: 210-221.

James, D. 2003. Pesticide susceptibility of two coccinellids (Stethorus punctum picipes and Harmonia axyridis) important in biological control of mites and aphids in Washington hops. Biocontrol Sci. Technol. 13: 253-259.

Lorenzana, A., H. Mendoza, and M. Seco. 2009. Thresholds for management of Phorodon humuli (Hemiptera: Aphididae) on Hops. J. Entomol. Sci. 44: 198-208.

Lorenzana, A., H. Mendoza, M. Seco, and P. Casquero. 2013. Population dynamics and integrated control of the damson-hop aphid Phorodon humuli (Schrank) on hops in Spain. Span. J. Agric. Res.11: 505-517.

Lovinger, A., D. Liewehr, and W. Lamp. 2000. Glandular trichomes on alfalfa impede searching behavior of the PLH parasitoid. Biol. Control 18: 187-192.

Lu, Z., P. Zhu, G. Gurr, X. Zheng, D. Read, K. Heong, Y. Yang, and H. Xu. 2014. Mechanisms for flowering plants to benefit arthropod natural enemies of insect pests: prospects for enhanced use in agriculture. Insect Sci. 21: $1-12$.

Magie, R. O. 1944. Disease and insect control on hops; technical bulletin 708. Cornell University. New York State Agricultural Experiment Station, Geneva, NY.

Mahaffee, W., S. Pethybridge, and D. Gent (Eds). 2009. Compendium of Hop Diseases and Pests. American Phytopathological Society Press, St. Paul, $\mathrm{MN}$.

Meagher, R., and J. Meyer. 1989. Influence of ground cover and herbicide treatments on Tetranychus urticae populations in peach orchards. Exp. Appl. Acarol. 9: 149-158.

Root, R. 1973. Organization of a plant-arthropod association in simple and diverse habitats: The fauna of collards (Brassica oleracea). Ecol. Monogr. 43: 94-125.

SAS Institute. 2014. PROC user's manual, version 9.4. SAS Institute, Cary, NC.

Schweiger, O., J. Maelfait, W. Windgerden, F. Hendrickx, R. Billeter, and M. Spellmans. 2005. Quantifying the impact of environmental factors on arthropod communities in agricultural landscapes across organizational levels and spatial scales. J. Appl. Ecol. 42: 1129-1139.

Straub, C., N. Simasek, M. Gapinski, R. Dohm, E. Aikens, S. Muscella. 2013. Influence of non-host plant diversity and natural enemies on the PLH, Empoasca fabae, and pea aphid, Acyrthosiphon pisum, in alfalfa. J. Pest Sci. 86: $235-244$

Swezey, S., D. Nieto, and J. Bryer. 2007. Control of Western tarnished plant bug Lygus hesperus Knight (Hemiptera: Miridae) in California organic strawberries using alfalfa trap crops and tractor-mounted vacuums. Environ. Entomol. 36: 1457-1465. 
Tuovinen, T. 1994. Influence of surrounding trees and bushes on the phytoseiid mite fauna on apple orchard trees in Finland. Agric. Ecosyst. Environ. 50: 39-47.

Turner, S., C. Benedict, H. Darby, L. Hoagland, P. Simonson, R. Sirrine, and K. Murpy 2011. Challenges and opportunities for organic hop production in the United States. Agron. J. 103: 1-10.

USA Hops. 2008. Hop growing in Washington. USA Hops, Yakima, WA.
Woods, J., A. Dreves, D. James, J. Lee, D. Walsh, and D. Gent. 2014. Development of biological control of Tetranychus urticae (Acari: Tetranychidae) and Phorodon humuli (Hemiptera: Aphididae) in Oregon hop yards. J. Econ. Entomol. 107: 570-581.

Wyss, E., U. Niggli, and W. Nentwig. 1995. The impact of spiders on aphid populations in a strip-managed apple orchard. J. Appl. Entomol. 119: $473-478$. 